\title{
Surfaces
}

\section{Feminism and Hybridity}

\section{Roundtable 4}

\section{Sabina Sawhney}

Volume 7, 1997

\section{LE FÉMINISME HORS DE LUI-MÊME}

FEMINISM BESIDE ITSELF

URI : https://id.erudit.org/iderudit/1064812ar

DOI : https://doi.org/10.7202/1064812ar

Aller au sommaire du numéro

\section{Éditeur(s)}

Les Presses de l’Université de Montréal

ISSN

1188-2492 (imprimé)

1200-5320 (numérique)

Découvrir la revue

Citer cet article

Sawhney, S. (1997). Feminism and Hybridity: Roundtable 4. Surfaces, 7.

https://doi.org/10.7202/1064812ar d'utilisation que vous pouvez consulter en ligne. 


\section{Feminism and Hybridity Roundtable 4}

Sabina Sawhney

Daemen College

Surfaces Vol. VII.113 (v.1.0A - 28/06/1997) - ISSN:

1188-2492

Copyright for texts published in Surfaces remains the property of authors. However, any further publication should be accompanied by an acknowledgement of Surfaces as the place of initial publication.

I would like to discuss the nexus between feminism and women. Probably the most restricting romance that feminism has engaged in unquestioningly has been its coupling with "woman"-both in its gendered and sexed manifestations. I would like to suggest that if we introduce a third party to this romance, the connection between women and feminism is no longer readily apparent. And the third that I want to bring into this affair are the hijras of India.

In response to: "What is a hijra?" asked by anthropologist, Nanda, the hijras offered a double narrative. While some of them tried to explain their being through various legends and myths from the Hindu religion, the rest attempted to demonstrate their existence by revealing their private parts. As Nanda recounts, "In some cases, a hijra I was talking with would jump to her feet, lift up her skirt, and, displaying her altered genitals, would say, 'See, we are neither men nor women!'"[ $\underline{\mathbf{1}}$ ]

These two responses seem analogous to the most frequently expressed feeling of the hijras about themselves-"neither here nor there." Various explanations offered by the experts suffer a similar fate. Attempts to categorize the hijras-as transvestites or transsexuals, as eunuches or castrated men, or even as 
providing institutionalized support for homosexuality-all seem either inappropriate or incomplete.[ 2 ] The very existence of hijras seems to be built around a number of disjunctions and paradoxes, all of which defy any simple or singular understanding.

The term "hijra" does not offer any easy resolutions. Derived from the Arabic, 'ijara,' which refers to eunuches or castrated men, hijra in common Indian parlance is an umbrella name referring to eunuches or men who have emasculated themselves, intersexed people, men and women with genital malfunction, hermaphrodites, persons with indeterminate sexual organs, impotent men, male homosexuals, and even effeminate men who are hijra imposters. The only common feature among them is their mode of dressing: they all adopt feminine costumes and apparel. They live in communes ranging from five to fifteen people and traditionally earn their living by collecting alms and receiving payment for performances at weddings, births, and festivals.

When individuals join a hijra community, they take female names and use female kinship terms, such as "sister," "aunt," or "grandmother" for each other. In public transport or other public accommodations, hijras request the "ladies only" seating, and periodically demand to be counted among the females in the census. Despite all this, however, the hijras evince no interest in "passing," as do many Western transsexuals or transvestites. That is to say there is no attempt to seriously imitate or to be considered indistinguishable from the "normal" woman in Indian society. In fact, it is not at all uncommon to see hijras wearing sarees and sporting beards of several days' growth. Their gestures and dress burlesque feminine behavior, and their performances and mannerisms are exaggerated to the point of caricature. They also use sexually explicit language and gestures in opposition to the Indian ideal of demure and restrained femininity. The hijras seem to engage in a deliberate parodic rendition of a culturally validated model of feminine behavior.

Straddling the boundaries between male and female, as well as between masculinity and femininity, the hijras present an obvious threat to any society which is based on these binary divisions. In fact, due to their indeterminate genders, the hijras unsettle our accepted modes of categorization and identification. 
The apparently insurmountable problems that confront us as we try to categorize the hijras bear, in some ways, a remarkable similarity to the predicaments posed by the issue of identity within feminism: women and hijras have more than just their dress in common. The group called "hijras" and the group named "women" are analogous in being impossible to categorize. Just as it is not practical to determine who, or even what, exactly constitutes the "hijras"-impossible to label them in terms of their gender, their sexual orientation, or profession-similarly the people collected under the title of women are inaccesible to any single, overarching identity. And herein lies the problem for feminism. The impetus propelling the feminist movement has been the desire to see a greater representation of women in a wide-ranging spectrum of discourses ranging from the political to the legal to the socio-cultural as well as the academic. This motivating force, however, has foundered precisely due to the difficulty of categorizing women, of defining or discovering their identity. That is to say, the demand for greater representation must, after all, emerge in concert with a definition of the subject on whose behalf this demand is being expressed. But it is this foundational premise of definition, of a pure and simple categorization, one that will enable us to recognize that the signifier "woman" has an explicit, unambiguous, transparent, and precise signified, that has always eluded the feminists.

The fact that there can be no single identity to which we can attach the "woman" label poses a serious obstacle to feminism. If we accept that feminism as such is always defined in relation to women, then feminism leads us into very puzzling situations. Since the basis of feminism's self-definition-the category of women-is inherently unstable and protean in its manifestations, feminism has to engage in some tricky acrobatics in order to maintain itself and not fall flat on its face. One could, perhaps, designate feminism simply as a movement on behalf of women with the added rider that the term "women" includes within it all the various differences and diversities found within this group. This move, however, presupposes that women have a common identity which overrides their differences. Just as some hijras seem to think that their authentic identity will be exposed once the camouflaging costume is discarded, similarly feminism seems to be relying on the notion that the authentic identity of woman would be revealed once the drag is removed. That is to say, when her various 'clothes'-racial, ethnic, hetero/homosexual, class textured-are removed, the real, genuine woman would 
appear whose identity would pose no puzzles. But surely that is a dangerous assumption, for it not only prioritizes certain forms of identity formation over others, but also essentializes a sexual or gendered identity as already known in advance. We not only need to interrogate the way in which the concept of woman functions in the discourse of feminism but also review the two coordinates-sex and gender-which formulate this concept.

By bringing both "woman" and "female" under scrutiny, the hijras enable us to examine the role and necessity of feminism. We need to reconsider whether the opppositional strategies and the revisionist re-readings of culture that feminism has produced must be necessarily tethered to either gender or sexual determinations, or whether such an association fosters a monolithic vision of feminism that must maintain itself through repressions.

The presumed universality of feminism-all women, all the time-needs to be scrutinized more carefully, along with the assumption that we know a woman when we see one. But neither of the two suppositions can be held as absolute. If gender is a cultural determination, then "woman" must remain questionable. Let's look at the problem of feminism from another direction. Whose concerns will feminism/s not address? Well, the answer, obviously, is: men's. However, how do we define men? After all, a number of studies have established that within the structures of a patriarchal society one method of asserting hegemonic control by a particular group is through the feminization of the rest of the population.[ $\underline{\mathbf{3}}$ ] The arbitrary division of human qualities as being either masculine or feminine, and the prioritizing of the former over the latter, leads to the frequent assertions of the dominant groups that the subjugated peoples possess feminine qualities which require that they be ruled and controlled.[ $\underline{4}$ ] That is, if one is not born but made a woman, then men can be women just as easily. This cultural feminization, as opposed to biological determination, puts a new wrinkle in our considerations of the manifold subjects of feminisms. But a recourse to culture and a denial of nature still does not satisfactorily answer all our questions. To understand this fully, we must return to the hijras.

The more we learn from the hijras the harder it is for us to accept feminism the way it has hitherto been defined. For the hijras insistently call into question the parameters that delimit feminism and its scope. In fact, by refusing to accede to demands that they announce 
their identity in terms of a binary, the hijras create a wedge between the signifier-feminism, and its signifiedwoman. The sign no longer functions as significant. The very idea of feminism when allied to women assumes the existence of a binary opposition between men and women. We have already seen how that opposition cannot be maintained in terms of a gender divide. The hijras, however, tell us that it cannot be maintained even in terms of a sexual divide.

It is by now a veritable commonplace of cultural criticism that sex and gender do not have a natural or innate bond. In other words, the old argument about nature and culture is replayed in terms of a biological sex and a culturally inscribed notion of gender.[ $\underline{\mathbf{5}}$ ] What this means for most of us is that while biology or anatomy may be destiny, gender (or how we deal with a biology of sex) lies within the realm of free will.[ $\underline{\mathbf{6}}$ ] On the one hand, the hijras certainly seem to validate the truth of this formulation. By parodying and exaggerating feminine gestures, the hijras demonstrate the manner in which a female body is culturally constructed to articulate its gender. By splitting sex from its gender, they seem to deconstruct the way in which culture inscribes the relationship between sex and gender as natural. For most of the hijras (and transsexuals), gender is destiny, while anatomy may be subject to change. That is to say, the hijras actually indicate a basic flaw in this formulation, which seems to regard biology as being somehow outside the domain of culture. It is not only one's gender that belongs in the domain of culture but also one's sex.

I want to clarify that I am not denying that the linkage between sex and gender is artificial and culturally constructed. What I want to emphasize is that the division between the two is equally artificial: not that gender necessarily follows from sex but that both are unnaturally constructed. In other words, while most of us are perfectly willing to accept Beauvoir's formulation: "One is not born, but rather becomes, a woman,"[ 7 ] I want to insist that one is not born but rather becomes a female as well. Sex and gender are both products of culture. There can be no biological sex that exists in isolation (as a tabula rasa so to speak) from the gendered determinations of culture.[ $\underline{\mathbf{8}}$ ] The very sexing of the body is a response to cultural genderisms. Or to misquote Dr. Anne Fausto-Sterling slightly: "How small does a penis have to be before we can call it a clitoris?"[ 9 ] 
However, the adjudication or doctoring of a sexed identity through medicine is not the only reason to question radically the sex/gender opposition in terms of its alliance with the nature/culture divide.[ 10 ] The example presented by the hijras leads to a re-working of the whole nature/culture dichotomy. The demarcation between the two, such that both "nature" and "culture" exist as two identifiable and distinct spheres (though overlapping occasionally), is not authorized by any transcendent principle. The operation of the antithesis between nature and culture facilitates an understanding of the structural determinations of society. But this understanding is based on a false dichotomy: that we can identify what is natural and hence not formulated through human agency, and what is cultural and hence available for immediate access and intervention. But the opposition between the two, the drawing of the divisions is itself a human act-an act performed from within the constraints of culture. Thus it is not only the gendered notions of masculinity and femininity, but also the biological sexual determinations that are brought to a crisis by the hijras. The cultural effect of the hijras is to destabilize all such binary divisions, including sex and gender; the concepts of either an authentic woman or an authentic female are exploded.

If "woman" becomes a contested term, then we need to rethink the basic premises of feminism, including its name. If there is no natural, immediate connection between all of us and a culturally constructed woman or a human female, then we need to reconsider the roles and purposes of feminism for the future. That is not to say that the discourses and activities fuelled and inspired by feminism have only been for some phantasmic figure that does not exist. After all, almost everyone has been affected by these discourses and activities to a certain extent. But now we must look at the connection between feminism and this phantasmic figure and question whether this connection is one that should continue. That is to say, we must scrutinize the constitution of subjects for feminism and question what grants such subjects a legitimate status within the concerns of feminism. 


\section{NOTES}

1. Serena Nanda, Neither Man nor Woman: The Hijras of India (Belmont: California University Press, 1990), p.15.

2. See for instance G.M. Carstairs, The Twice Born (London: Hogarth Press, 1957) and M. Opler, "The Hijras of India and Indian National Culture," American Anthropologist, 62 (1960), pp. 505-511.

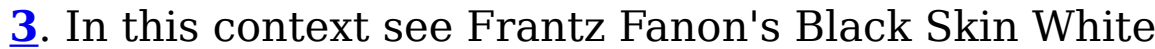
Masks, tr. Charles Lam Markmann (New York: Grove, 1967) and Ashis Nandy's The Intimate Enemy: Loss and Recovery of Self under Colonialism (Delhi: Oxford University Press, 1983).

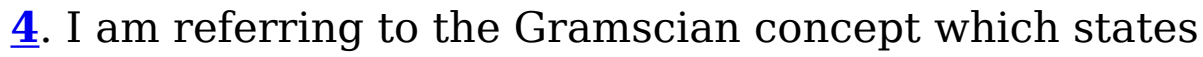
that hegemony functions by making the subjected peoples acquiesce to their subjugation through the force of opinion and persuasion. According to Gramsci: "the supremacy of a social group manifests itself in two ways, as 'domination' and as 'intellectual and moral leadership'....It seems clear... that there can, and indeed must be hegemonic activity even before the rise to power, and that one should not count only on the material force which power gives in order to exercise an effective leadership." Selections From the Prison Notebooks, eds. Quintin Hoare and Geoffrey Nowell Smith (London: Lawrence and Wishart, 1971), p.57.

$\underline{\mathbf{5}}$. Judith Shapiro defines the relationship between sex and gender as "at once a motivated and an arbitrary one. It is motivated insofar as there must be reasons for the crossculturally universal use of sex as a principle in systems of social differentiation; it is arbitrary, or conventional, insofar as gender differences are not directly derivative of natural, biological facts, but rather vary from one culture to another in a way in which they order experience and action. In any society the meaning of gender is constituted in the context of variety of domains-political, economic, etc.-that extend beyond what we think of gender per se." In "Transsexualism: Reflections on the Persistence of Gender and the Mutability of Sex," Body Guards: The Cultural Politics of Gender Ambiguity, eds. Julia Epstein and Kristina Straub (New York: Routledge, 1991), p. 271.

6. Free will in this context is merely used in opposition to biological or anatomical determinations. I do not mean to imply that choosing a gender is covered by, say, the Freedom of Choice Act. Currently, biology seems 
inaccessible to human intervention, determining whether we are born with a vagina or a penis. But what we do with these organs is, to a limited extent, up to us. What the possession of these organs means is determined by culture; the only 'free will' we possess is in nuancing those meanings slightly, not in overthrowing the bounds of gender.

7. "No biological, psychological, or economic fate determines the figure that the human female presents in society; it is civilization as a whole that produces this creature." The Second.Sex, tr. H.M. Parshley (New York: Vintage Books, 1974), p. 301.

$\underline{\mathbf{8}}$. Judith Butler makes the same argument when she writes about the "construal of 'sex' no longer as a bodily given on which the construct of gender is artificially imposed, but as a cultural norm which governs the materialization of bodies" in Bodies That Matter (New York: Routledge, 1993), p. 3.

9. Anne Fausto-Sterling, Myths of Gender: Biological Theories About Women and Men, (New York: Basic Books, 1985), pp. 84-85. The interpellation of a subject as male or female may be most visible in medical practices, but is not specific to them. If we accept that sex and sexuality are determined by cultural constraints, then the way in which we articulate our sex depends on our adoption of norms which makes such articulation comprehensible. In other words, the subject assumes a sex and then depicts that sex through the various rules and regulations which govern its performance.

10. The management of sex through medical intervention is a lot more common in the West than in India. As Suzanne J. Kessler reports in "The Medical Construction of Gender: Case Management of Intersexed Infants" physicians determine the sex of intersexed babies, basing their deliberations on "such factors as the 'correct' length of the penis and the capacity of the vagina." Signs, 16.1 (1990), p. 3.

Accueil Surfaces | Table des matières | Recherche Surfaces Home Page | Table of Contents | Search

PUM | Livres | Revues | Publications électroniques | Vente et distribution 